\title{
Economics of Organic vs Inorganic Rice Production: A Case of Chitwan District of Nepal
}

Bidya Kiran Sapkota $^{\circledR}$, Ananta Prakash Subedi, Kalyani Mishra Tripathi and Shiva Chandra Dhakal

Agriculture and Forestry University, Rampur, Chitwan, Nepal: @: sapkota.bidya @gmail.com

(iD) : https://orcid.org/0000-0002-6929-4436

Received 12 Oct 2020, Revised 27 Dec 2020, Accepted 16 Jan 2021, Published 30 April 2021

Scientific Editors: Krishna Prasad Timsina, Jiban Shrestha, Yuga Nath Ghimire

Copyright $\odot 2021$ NARC. Permits unrestricted use, distribution and reproduction in any medium provided the original work is properly cited.

The authors declare that there is no conflict of interest.

\section{ABSTRACT}

Rice (Oryza sativa L.) is the major staple food crop of Nepal. A research was conducted in December, 2019 to examine the economic viability of organic rice farming and factors affecting its adoption. Fulbari area of Chitwan district of Nepal was purposively selected for this study on consultation with Agriculture Knowledge Centre, Chitwan and review of past works which showed good practice of organic rice farming. A total of 100 farm households, 50 organic and 50 inorganic were selected using simple random sampling. Primary data were collected through a pre-tested semi-structured interview schedule, while secondary data were collected from related publications. The probit regression analysis showed that the six variables were statistically significant for the decision to adopt organic rice farming, they are: number of schooling years of the household head $(\mathrm{p}=0.014)$, annual household income from agriculture $(\mathrm{p}=0.012)$, membership of any agricultural organization $(\mathrm{p}=0.000)$, subsidy in other inputs in addition to seed and fertilizers $(\mathrm{p}=0.000)$, area of rice cultivated land $(\mathrm{p}=0.007)$ and awareness on climate change (0.086). The benefit cost ratio of organic rice production (2.2) was higher as compared to inorganic (1.9) which showed that the profitability in organic rice production was higher than in inorganic. Furthermore, indexing identified- lengthy certification process $(0.85)$ as the first major hindrance in adoption of organic rice farming followed by lack of proper organic market $(0.68)$, high cost of organic seed and fertilizer (0.56), lack of knowledge and trainings on organic farming (0.48) and lack of government support such as grants and premium price (0.44) as the second, third, fourth and fifth hindrances respectively. The government should promote organic rice farming, prioritizing the small scale and marginal farmers by giving subsidies and premium, facilitating in certification and marketing, and providing knowledge about climate change.

Keywords: Benefit cost ratio, Indexing, Organic farming, Probit regression, Rice

सारांश

धान नेपालको प्रमुख खाय बाली हो। अर्गानिक धान खेतीको आर्थिक विश्लेषण तथा यस खेतीको अनुशरणमा प्रभाव पार्ने कारकहरुको पहिचान गर्ने उदेश्यले डिसेम्बर २०१९ मा यो अध्ययन गरिएको हो।यस अध्ययनका लागि कृषि ज्ञान केन्द्रको परामर्श र विगतका भएका कामहरूको समीक्षाका आधारमा नेपालको चितवन जिल्लाको फुलबारी क्षेत्र चयन गरियो।कुल १०० किसान घरधुरी सिम्पल रेंडम स्यम्पिंग विधि प्रयोग गरेर छनोट गरियो, जसमध्ये $\% ०$ अर्गानिक धान खेती गर्ने र $\mathrm{C}_{0}$ अर्गानिक नगर्ने किसानहरु थिए। पूर्व परीक्षण गरिएको प्रश्नावली र सम्बन्धित प्रकाशित प्रतिवेदनहरुबाट आवश्यक तथ्यांक प्राप्त गरियो। यस अध्ययन अनुसार शिक्षा, कृषिजन्य आम्दानी, बिउबिजन तथा मल सहित अन्य उत्पादन सामग्रीमा अनुदान, धानखेती गरिएको जग्गाको क्षेत्रफल, जलवायु परिवर्तन बारे जानकारी र कृषि संस्थाको सदस्यता हुनुले अर्गानिक धान खेती अनुशरण गर्ने सम्भावनामा उल्लेख्य प्रभाव पारेको देखियो।यसैगरी, अर्गानिक धान खेती गर्ने किसानहरुको औसत लाभ लागत अनुपात २.२ पाइयो भने अर्गानिक नगर्गेहरूको १.९ मात्र पाइयो, यसबाट 
अर्गानिक धान खेती गर्ने किसानहरुको फाइदा नगर्नेहरुको तुलनामा बढ़रहेको देखियो। अर्गानिक खेती नगरेका किसानहरुको भनाइ अनुसार, अर्गानिक धान खेती अनुशरणमा मुख्य बाधकहरु ऋमशः झन्झटिलो प्रमाणीकरण प्रक्रिया, अर्गानिक बजारको अभाव, अर्गानिक खेती बारे ज्ञान र सिपको अभाव, अर्गानिक बिउ र मलको उच्च मूल्य र सरकारद्वारा अनुदान तथा प्रिमियम मूल्य नदिनु रहेको पाईयो।सरकारले साना तथा सीमान्तकृत किसानहरुलाई प्राथमिकतामा राखि अनुदान तथा प्रिमियम दिई, अर्गानिक प्रमाणीकरण र बजारीकरण लाई सहज बनाई जलबायु परिवर्तन सम्बन्धि ज्ञान दिई अर्गानिक धान खेतीको प्रवर्द्धन गर्नुपर्दछ।

\section{INTRODUCTION}

Rice (Oryza sativa L.) is the major staple food crop of Nepal; it is the member of the Poaceae family. Rice ranks the first among cereal crops in terms of area, production and productivity. The area, production and productivity of rice in Nepal in the fiscal year 2018/19 has been reported 1,491,744 ha, 5,610,011 mt and 3.76 t/ ha respectively. Moreover, rice has highest contribution to Agriculture Gross Domestic Product (AGDP). Rice is grown in three distinct major agro-ecological zones, which are Terai and Inner Terai (60900 masl), Mid hills (900-1,500 masl) and Mountains/high hills (1,500 - 3,050 masl) (MoALD 2020).

The cost of rice production is increasing in inorganic conventional farming due to increase in cost of inputs such as: chemical fertilizers, herbicides, pesticides and labor (Sapkota et al., 2018); in addition, inorganic agricultural practices has contributed to emission of greenhouse gases which causes global warming and ultimately promotes climate change (DFID 2004). Kassie and Zikhali (2009) reported that the inorganic farming has been criticized for it brought environmental, economic and social concerns. Bhatta et al (2009) reported that increasing use of agro-chemicals, higher production cost and deteriorating ecosystem health have advocated the need to change traditional and external input use agriculture towards safe and sustainable organic production. Organic systems do not apply herbicides, aquatic weeds are likely to be present in organic rice paddies and weeds have an additional decreasing effect on methane emissions (Inubushi et al 2001). Besides, the yields in organic and conventional rice production do not differ significantly (Rasul and Thapa 2004).

There have been past studies on economics of organic rice production (Adhikari 2011) and climate change adaptation strategy in rice farming (Khanal et al 2015) in Chitwan district. In addition, Mehmood et al (2011a) and Memon et al (2015) conducted research on economics of organic and inorganic wheat production in Pakistan. Moreover, there have been past studies in Fulbari, Chitwan, Nepal assessing the profitability in organic versus inorganic carrot production (Adhikari 2009, Singh 2015). However, the comparative assessment on profitability of organic versus inorganic rice production in Nepalese agricultural context is lacking; with this documentation, it will be quite easy for the farmers to take decision regarding selection of more profitable farming method. Also, identification of the socio-economic and farm characteristics that affects the adoption of organic rice farming needed to be done which will be helpful in future to enhance the adoption of improved technology. Moreover, identification and prioritization of the major hindrances in adoption of organic rice farming is necessary. Very few studies have been carried out in these concerns. In this context, this study aims to address these research gaps.

\section{METHODOLOGY}

\section{Selection of the study area, sampling procedure and data collection technique}

Chitwan district was purposively selected for this study; moreover, the Fulbari area which comes under Bharatpur Metropolitan City was selected. The selection of the study area was done on the basis of consultation with Agriculture Knowledge Centre, Chitwan and review of past works which showed that there is a good practice of organic rice farming. Altogether, 100 respondents (household heads), 50 organic and 50 inorganic rice growing farmers were selected as the samples for the purpose of the study, using simple random sampling technique. A pre-tested interview schedule was used to collect the primary information from the respondents. Also, relevant literatures were reviewed for the secondary information. 


\section{Methods and techniques of data analysis}

Data entry and analysis were done using the computer software packages like: Statistical Package for Social Science (SPSS), STATA and Microsoft Excel (MS-Excel). The following analyses were performed.

\section{Description of the major socio-economic variables and farm-characteristics}

The statistical description of the continuous variables such as age of the household head, number of schooling years, family size, number of economically active family members, total land holding, total rice cultivated land, annual household income from agriculture, Livestock Standard Unit (LSU), etc. were done using the t-test.

\section{Gross margin}

The gross margin associated with the organic and inorganic rice production was calculated and comparison was done to explore the financial superiority.

Gross margin = Gross return - Total variable cost

Where, Gross return $=$ Price $\mathrm{x}$ total quantity marketed

And, Total variable cost $=$ Summation of the cost incurred in all the variable items

\section{Benefit cost ratio}

Benefit cost ratio was estimated after calculating the total variable cost and gross return from rice cultivation in both organic and inorganic farming methods. The cost of production was calculated by summing the variable cost items in the production process. For calculating gross return, income from product sale (grains, straw) was accounted. Finally, the benefit- cost ratio was calculated by using the formula:

Benefit cost ratio $(\mathrm{BCR})=$ Gross return

Total variable cost

\section{Determination of the factors affecting the decision to adopt organic rice farming}

The probit regression was used to analyze the effect of different explanatory variables on the decision to adopt organic rice farming. To determine the factors affecting the adoption of improved agricultural technology, the probit model is used in many studies (Hattam 2006, Kafle 2010, Subedi et al 2017). The probit model is often used when a choice is to be made between two alternatives; in this study, the decision to either adopt or not adopt organic rice farming. From the perspective of an economist, an individual i makes a decision to adopt if the utility associated with that adoption choice $\left(\mathrm{V}_{\mathbf{1 j}}\right)$ is higher than the utility associated with the decision not to adopt (alternative choice), $\left(\mathrm{V}_{\mathbf{0}_{\mathbf{j}}}\right)$. Koop (2003) stated that the difference in utilities of the two alternative choices is stated as $Y_{\mathbf{j}}{ }^{*}=V_{\mathbf{1}}-\mathrm{V}_{\mathbf{0 j}}$ and the econometric specification of the model is given in its latent as:

$Y_{j}{ }^{*}=X_{j} \beta+e_{j}$

Where, $\mathrm{Y}_{\mathbf{j}}{ }^{*}$ is an unobserved (latent) random variable that defines farmer's binary (adoption) choices, $\mathrm{X}_{\mathrm{j}}$ is sets of explanatory variables associated with individual $j . \beta$ is a vector of coefficients associated with the explanatory variables while ej represents the random error terms defined as: e $\sim N(0,1)$. The relationship between the unobserved variable $\mathrm{Y}_{\mathbf{j}}{ }^{*}$ and the observed outcome $\left(\mathrm{Y}_{\mathbf{j}}\right)$ can be specified as:

$\mathrm{Yj}=1$, if $\mathrm{Yj}^{*} \geq 0$

$\mathrm{Yj}=0$, if $\mathrm{Yj}^{*}<0$

Probit model has the characteristic feature; the effect of independent variables on dependent variables is non-linear. It is a statistical model which aims to form a relation between probability values and explanatory 
variables ensuring that the probability value remains between 0 and 1 . For the statistical analysis of the model, STATA software package was used.

In this study, adoption of organic rice farming will be based on an assumed underlying utility function. According to this theory, organic rice farming will be adopted by the farmer, if the utility obtained from it exceeds that non-adoption. The farmer's behaviour towards organic rice farming is described by the following equations;

$\operatorname{Prob}\left(\mathrm{Y}_{\mathrm{i}}^{*}\right)=\sigma 0+\Sigma \delta \mathrm{nXi}+\varepsilon \mathrm{i} \quad \ldots \ldots \ldots \ldots \ldots \ldots \ldots$ Equation 1

$\operatorname{Prob}($ Adopt $=1)=\Upsilon^{\prime} \mathrm{K}+\varepsilon \mathrm{i}$ Equation 2

Where,

$\mathrm{Y}^{*}{ }_{\mathrm{i}}=\mathrm{A}$ latent variable representing the propensity of a farm household $\mathrm{i}$ to adopt organic rice farming (1 if adopt and 0 otherwise).

$\mathrm{X}_{\mathrm{i}}=\mathrm{K}=$ the vector of households' socio-economic and farm characteristics and variables that influence the adoption decision

$\sigma 0, \delta \mathrm{n}=$ parameters to be estimated

$\varepsilon i=$ error term of the $i^{\text {th }}$ farm households

$\mathrm{i}=1,2,3, \ldots \mathrm{n}$ farm households

Table 1. The statistical description of the explanatory variables used in the probit regression

\begin{tabular}{llll}
\hline Variables & Description & Value & $\begin{array}{l}\text { Expected } \\
\text { sign }\end{array}$ \\
\hline age & Age of the household head & Years (in number) & $+/-$ \\
\hline Edu & $\begin{array}{l}\text { Number of schooling years of the household } \\
\text { head }\end{array}$ & Years (in number) & $+/-$ \\
\hline Gen & Gender of the household head & Male=1, otherwise $=0$ & $+/-$ \\
\hline econ_fm & Economically active members in the family & Numeric value & $+/-$ \\
\hline log_ahi_ag & $\begin{array}{l}\text { Logarithm of annual household income } \\
\text { from agriculture }\end{array}$ & Numeric log value & $+/-$ \\
\hline Lsu & Livestock standard unit & Numeric value & + \\
\hline mem-org & $\begin{array}{l}\text { Membership of any } \\
\text { organization agricultural }\end{array}$ & $\begin{array}{l}\text { If had membership }=1, \\
\text { otherwise }=0 \text { (Dummy) }\end{array}$ & + \\
\hline $\begin{array}{l}\text { subs_other_seed_ } \\
\text { fert }\end{array}$ & $\begin{array}{l}\text { Subsidy in other inputs in addition to in seed } \\
\text { and fertilizers }\end{array}$ & $\begin{array}{l}\text { If had got subsidy }=1, \\
\text { otherwise }=0 \text { (Dummy) }\end{array}$ & $+/-$ \\
\hline log_rice_land & Logarithm of rice cultivated land & Numeric log value & + \\
\hline hrd_cc & Heard about climate change & $\begin{array}{l}\text { If had heard = 1, } \\
\text { otherwise }=0 \text { (Dummy) }\end{array}$ & + \\
\hline
\end{tabular}

Note: + indicates positive sign, - indicates negative sign

The probit model specified in this study to analyze the factors affecting farmers' decisions to adopt organic rice farming is,

$\operatorname{Pr}$ (adopting organic rice farming $=1)=f\left(b_{0}+b_{1} X_{1}+b_{2} X_{2}+b_{3} X_{3}+b_{4} X_{4}+b_{5} X_{5}+b_{6} X_{6}+b_{7} X_{7}+b_{8} X_{8}+\right.$ $\mathrm{b}_{9} \mathrm{X}_{9}+\mathrm{b}_{10} \mathrm{X}_{10}$

where,

$\operatorname{Pr}=$ Probability score of adopting organic rice farming

$\mathrm{X}_{1}=$ Age of the household head (in years)

$\mathrm{X}_{2}=$ Number of schooling years of the household head (in years)

$\mathrm{X}_{3}=$ Gender of the household head (dummy) 
$\mathrm{X}_{4}=$ Economically active members in the family (in number)

$\mathrm{X}_{5}=$ Logarithm of annual household income from agriculture (log value)

$\mathrm{X}_{6}=$ Livestock standard unit (numeric value)

$\mathrm{X}_{7}=$ Membership of any agricultural organization (dummy)

$\mathrm{X}_{8}=$ Subsidy in other inputs in addition to in seed and fertilizers (dummy)

$\mathrm{X}_{9}=$ Rice cultivated land (log value)

$\mathrm{X}_{10}=$ Heard about climate change (dummy)

And, $b_{1}, b_{2} b_{10}=$ Probit coefficient, $b_{0}=$ Regression coefficient

The explanatory variables included in the above probit model has been selected reviewing the past research relating to factors affecting the adoption of improved agricultural technology (Kafle 2010, Singh 2015, Subedi et al 2015, Subedi et al 2017, Adhikari et al 2018 and Subedi et al 2019a).

\section{Hindrances in adoption of organic rice farming}

To explore the major hindrances in adoption of organic rice farming, indexing/scaling technique was applied and the index was calculated. Subedi and Dhakal (2015) and Subedi et al (2019) also used the indexing technique to identify the major problems associated with use of improved agricultural technology and crop production respectively. The weighted indexes were calculated and the hindrances were ranked by using five point scales based on their responded frequencies. The formula used to determine the index for intensity of various hindrances was,

$$
I_{\text {hind }}=\sum \frac{s_{i} f_{i}}{N}
$$

where, $I_{\text {hind }}=$ index value for severity or intensity of the hindrances

$\sum=$ summation

$\mathrm{s}_{\mathrm{i}}=$ scale value at $\mathrm{i}^{\text {th }}$ intensity/severity

$\mathrm{f}_{\mathrm{i}}=$ frequency of the $\mathrm{i}^{\text {th }}$ severity

$\mathrm{N}=$ total no. of the respondents $=\sum \mathrm{f}_{\mathrm{i}}$

Where, $\mathrm{I}_{\text {hind }}=$ index, $0<\mathrm{I}<1$

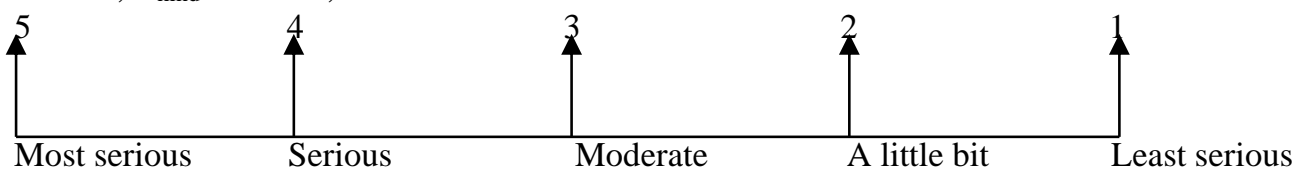

Figure 1. Scale of rating for the hindrances in adoption of organic rice farming

\section{RESULTS}

\section{Description of the major socio-economic continuous variables}

The statistical description of the continuous variables is shown in table 2. The mean total land holding was 24 kattha and mean rice cultivated land was 19 kattha. Mean total land holding ( 28 kattha) of inorganic rice farmers was significantly higher at $10 \%$ level of significance compared to organic rice farmers (20 kattha); moreover, the mean rice cultivated land was also significantly higher among inorganic rice farmers (21.5 kattha) when compared to organic rice farmers (16.2 kattha) at 10\% level of significance (Table2).

Table 2.Statistical description of the major socio-economic and demographic variables

\begin{tabular}{llllll}
\hline Variables & $\begin{array}{l}\text { Total } \\
\text { mean }\end{array}$ & $\begin{array}{l}\text { Organic } \\
\text { farmers }\end{array}$ & $\begin{array}{l}\text { Inorganic } \\
\text { Farmers }\end{array}$ & $\begin{array}{l}\text { Mean } \\
\text { Difference }\end{array}$ & $\begin{array}{c}\text { T }- \\
\text { value }\end{array}$ \\
\hline Age of the household head (in years) & 51.32 & 52 & 50.64 & 1.36 & 0.624 \\
\hline Number of schooling years of the household head & 10.46 & 10.26 & 10.66 & -0.40 & -0.559 \\
\hline Family size (Total number of family members) & 4.90 & 4.96 & 4.84 & 0.12 & 0.343 \\
\hline Number of economically active family members & 3.01 & 3 & 3.02 & -0.02 & -0.087 \\
\hline Livestock Standard Unit (LSU) & 1.62 & 1.57 & 1.67 & -0.1 & -0.210 \\
\hline
\end{tabular}




\begin{tabular}{lccccc}
\hline Total land holding (kattha) & 24.075 & 20.11 & 28.04 & -7.93 & - \\
& & & & & $1.959^{*}$ \\
\hline Rice cultivated land (kattha) & 18.89 & 16.22 & 21.56 & -5.34 & - \\
& & & & $1.621^{*}$ \\
\hline & & & & & -23430 \\
\hline Annual household income from agriculture (NRs) & 149415 & 137700 & 161130 & -0.787 \\
\hline * indicate significance at 10\% level; Source: Field survey, 2019
\end{tabular}

\section{Factors affecting the decision to adopt organic rice farming}

According to Rogers and Shoemaker (1971), adoption is the mental process through which an individual passes from the first stage of awareness or knowledge of an innovation to a decision to adopt or reject and then confirmation of this decision. To identify the factors affecting the decision to adopt organic rice farming, a probit regression was used. The binary response of the 100 respondents was coded as; adopters $=1$ and 0 otherwise. The Wald test $\left(\mathrm{LR} \mathrm{chi}^{2}\right)$ for the model indicated that the model has good explanatory power at the $1 \%$ level. This means that all the explanatory variables included in the model jointly influence farmer's probability of adoption of organic rice farming. The probit model estimation gave a pseudo $\mathrm{R}^{2}$ of 0.75 which implies that the explanatory variables included in the model explain $75 \%$ of the variation in the dependent variable. The area under ROC curve for the regression is 0.98 which reveals that the model presents adequate discrimination. The overall predictive power of the model is $92 \%$. The goodness of fit yields a chi- square with a large $\mathrm{p}$ value indicating that the model presents good adequacy and fits the data well. The link test shows that [hatsq] is not significant, meaning the model did not have omitted variables. The interpretation is shown in Table3.

Table 3. Factors affecting the decision to adopt organic rice farming

\begin{tabular}{lccccc}
\hline Variables & Coefficients & $\mathbf{P}>|\mathbf{z}|$ & Standard error & $\mathbf{d y} / \mathbf{d} \mathbf{x}^{\mathbf{b}}$ & S.Eb \\
\hline age & -0.0065 & 0.842 & 0.033 & -0.0025 & 0.1275 \\
\hline Edu & $-0.278^{* *}$ & 0.014 & 0.113 & -0.1088 & 0.0458 \\
\hline Gen & -0.8383 & 0.225 & 0.691 & -0.3248 & 0.2527 \\
\hline econ_fm & -0.1973 & 0.438 & 0.2545 & -0.077 & 0.0999 \\
\hline log_ahi_ag & $4.921^{* *}$ & 0.012 & 1.9515 & 1.928 & 0.7488 \\
\hline Lsu & 0.1526 & 0.394 & 0.1789 & 0.0597 & 0.0702 \\
\hline mem-org & $3.3395^{* * *}$ & 0.000 & 0.8936 & 0.865 & 0.1009 \\
\hline subs_other_seed_fert & $2.5475^{* * *}$ & 0.000 & 0.6879 & 0.7814 & 0.1255 \\
\hline log_rice_land & $-6.4458^{* * *}$ & 0.007 & 2.3840 & -2.5255 & 0.9104 \\
\hline hrd_cc & $1.0841^{*}$ & 0.086 & 0.6315 & 0.3868 & 0.1937 \\
\hline Constant & $-17.4413^{* *}$ & 0.026 & 7.8296 & & \\
\hline
\end{tabular}

*** Significant at $1 \%$ level; ** Significant at $5 \%$ level; * Significant at $10 \%$ level

$b$ Marginal change in probability evaluated at the sample means

\begin{tabular}{ll}
\hline Summary Statistics & \\
\hline Number of observation(N) & 100 \\
\hline Log likelihood & -17.593258 \\
\hline LR chi2 (10) & $103.44 * * *($ Prob $>$ chi2 $=0.0000)$ \\
\hline Pseudo R2 & 0.7462 \\
\hline Link test & hat. sq. coef. $=0.0805, \mathrm{z}=1.15(\mathrm{p}>|\mathrm{z}|=0.250)$ \\
\hline Goodness of fit test & Pearson chi2 $(79)=49.31$. Prob $>$ chi2 $=0.9964$ \\
\hline Area under ROC curve & 0.9796 \\
\hline Overall correct prediction & 92 percent
\end{tabular}


The probit regression analysis showed that the six variables were statistically significant for the decision to adopt organic rice farming, they are: number of schooling years of the household head (in years), annual household income from agriculture (log value), membership of any agricultural organization (dummy), subsidy in other inputs in addition to in seed and fertilizers (dummy), rice cultivated land (log value) and heard about climate change (dummy) (Table3).

The probit model revealed that with the increase in number of schooling years by one, the probability of making decision for adoption of organic rice farming decreases by $11 \%$ (5\% level of significance). Moreover, annual household income from agriculture was found to have positive and significant effect on adoption of organic rice farming at 5\% level of significance. With the increase in agricultural annual household income by $1 \%$, the probability of making decision for adoption of organic rice farming increases by $1.9 \%$. For farmers who are member of any agricultural organization, the probability of making decision for adoption of organic rice farming is $86.5 \%$ more as compared to farmers having no membership (at $1 \%$ level of significance). The size of rice cultivated land was found to be negatively and significantly ( $1 \%$ level) related to the decision relating adoption of organic rice farming. With the increase in size of the rice cultivated land by $1 \%$, the probability of making decision of adoption of organic rice farming decreases by $2.5 \%$. The probability of making decision to adopt organic rice farming is $78 \%$ more for the farmers who had got subsidy in other inputs in addition to in seed and fertilizers (at $1 \%$ level of significance). The probability of making decision to adopt organic rice farming is found to be $38.6 \%$ more for the farmers who had heard about climate change as compared to farmers who hadn't (at 10\% level of significance) (Table 3).

\section{Comparative financial analysis of organic versus inorganic rice farming}

Total variable cost of production: The total variable cost of production per kattha in organic rice farming (NRs.3119) is found to be less than inorganic rice farming (NRs. 3859). Except total cost of fertilizers, all other costs were calculated higher in inorganic rice farming as compared to organic rice farming. Labour cost was the major cost item having the highest share in the total cost in organic $(63.6 \%)$ as well as inorganic $(64 \%)$ rice farming. However, the labor cost incurred per kattha of land in inorganic rice farming (NRs. 2468) was found to be higher than organic rice farming (NRs.1984) (Table 4).

Table 4. Total variable cost in organic versus inorganic rice production

\begin{tabular}{l|l|c|c}
\hline S.N. & Costs (NRs./ Kattha) & $\begin{array}{c}\text { Organic rice } \\
\text { production }\end{array}$ & $\begin{array}{c}\text { Inorganic rice } \\
\text { production }\end{array}$ \\
\hline 1. & Seed & $81(2.6)$ & $132(3.4)$ \\
\hline 2. & Fertilizers & $625(20)$ & $406(10.6)$ \\
\hline 2.1. & Inorganic (Urea, DAP, MOP) & 0 & 191 \\
\hline 2.2. & Organic (FYM, oilcake) & 625 & 215 \\
\hline 3. & Labour cost & $1984(63.6)$ & $2468(64)$ \\
\hline 3.1. & Nursery preparation and transplanting & 816 & 906 \\
\hline 3.2. & Weeding & 250 & 384 \\
\hline 3.3. & Harvesting, threshing and packaging & 918 & 1178 \\
\hline 4. & Machinery cost (tractor cost in field preparation) & $375(12)$ & $518(13.4)$ \\
\hline 5. & Chemical pesticides & 0 & $104(2.7)$ \\
\hline 6. & Chemical herbicides & 0 & $103(2.6)$ \\
\hline 7. & Other cost (Storage, irrigation) & $54(1.8)$ & $128(3.3)$ \\
\hline & Total variable cost & $3119(100)$ & $3859(100)$ \\
\hline
\end{tabular}

Note: Figures in the parentheses indicate percent

Source: Field survey, 2019 
Total returns: The total returns from inorganic rice production (NRs. 7246) was found to be higher as compared to organic rice production (NRs. 7000). The returns from grain and straw in organic rice production was calculated NRs. 5715 and NRs. 1285 respectively; while that of in inorganic rice production was NRs. 5944 and NRs.1302 respectively (Table5). The higher returns in inorganic rice production is due to its higher productivity (171 kg/ Kattha) as compared to the productivity in organic rice production (166 $\mathrm{kg}$ / Kattha) (Field survey, 2019).

Table 5. Total returns in organic versus inorganic rice production

\begin{tabular}{llcc}
\hline SN & Returns (NRs./ Kattha) & Organic rice production & Inorganic rice production \\
\hline 1. & Grain & $5715(81.6)$ & $5944(82)$ \\
\hline 2. & Straw & $1285(18.4)$ & $1302(18)$ \\
\hline & Total returns & $7000(100)$ & $7246(100)$ \\
\hline
\end{tabular}

Note: Figures in the parentheses indicate percent

Source: Field survey, 2019

Price of grain: The average price of the grains for organic rice was calculated NRs. $32 / \mathrm{kg}$ if sold on current year of production while it fetches NRs. $41 / \mathrm{kg}$ if sold on next year. On an average, about $64 \%$ of total organic rice production is sold on current year and rest $36 \%$ on next year. Moreover, the average price of the grains for inorganic rice was calculated NRs. $31 / \mathrm{kg}$ if sold on current year of production while it fetches NRs. $40.5 / \mathrm{kg}$ if sold on next year. Also, on an average, about $54 \%$ of total inorganic rice production is sold on current year and rest $46 \%$ on next year.

Gross margin: The gross margin is positive for both organic as well as inorganic rice production which indicates the financial viability of rice farming. Moreover, the gross margin in organic rice production (NRs. 3881/ kattha) was found to be higher than inorganic rice production (NRs. 3387/kattha) which shows that organic rice production is financially sounder than inorganic rice production (Table 6).

Benefit cost ratio: The benefit cost ratio (BCR) of organic rice production was 2.2; in addition, the BCR of inorganic rice production was calculated 1.9. Though both the methods of rice farming- organic and inorganic were found to be financially sound, the results showed the superiority of organic rice production to inorganic rice production in terms of financial benefit (Table 6).

Table 6. Financial indicators in organic versus inorganic rice production

\begin{tabular}{lcc}
\hline Particulars & Organic rice production & Inorganic rice production \\
\hline Total variable cost & NRs. 3119/ Kattha & NRs. 3859/ Kattha \\
\hline Gross returns & NRs. 7000/ Kattha & NRs. 7246/ Kattha \\
\hline Gross margin & NRs. 3881/ Kattha & NRs. 3387/ Kattha \\
\hline Benefit-cost ratio (B:C ) & 2.2 & 1.9 \\
\hline
\end{tabular}

Source: Field survey, 2019

\section{Hindrances in adoption of organic rice farming}

When the inorganic rice growers were asked to list and rank the major hindrances in adoption of organic rice farming, they ranked- Lengthy certification process $(0.85)$ as the first major hindrance followed by lack of proper organic market (0.68), high cost of organic seed and fertilizer (0.56), lack of knowledge and trainings on organic farming (0.48) and lack of government support such as grants and premium price (0.44) as the second, third, fourth and fifth hindrances respectively (Table 7). 
Table 7. Major hindrances in adoption of organic rice farming

\begin{tabular}{llccccccc}
\hline $\begin{array}{l}\text { S. } \\
\mathbf{N}\end{array}$ & Problems & $\begin{array}{l}\text { Most } \\
\text { serious }\end{array}$ & Serious & Moderate & $\begin{array}{l}\text { A little Least } \\
\text { bit }\end{array}$ & $\begin{array}{l}\text { Index } \\
\text { value }\end{array}$ & Rank \\
\hline 1 & High cost of organic seed and fertilizer & 8 & 6 & 14 & 11 & 11 & 0.56 & III \\
\hline 2 & $\begin{array}{l}\text { Lack of knowledge and trainings on } \\
\text { organic farming }\end{array}$ & 1 & 7 & 21 & 4 & 17 & 0.48 & IV \\
\hline 3 & Lengthy and costly certification process & 36 & 0 & 4 & 10 & 0 & 0.85 & I \\
\hline 4 & Lack of proper organic market & 0 & 37 & 2 & 4 & 7 & 0.68 & II \\
\hline 5 & $\begin{array}{l}\text { Lack of government support such as } \\
\text { grants and premium price }\end{array}$ & 5 & 0 & 9 & 21 & 15 & 0.44 & V \\
\hline
\end{tabular}

Source: Field survey, 2019

\section{DISCUSSION}

\section{Factors affecting the decision to adopt organic rice farming}

The significant but negative relationship between number of schooling years and adoption of organic rice farming revealed from this study is in line with the findings of Subedi et al (2019a) and Uematsu and Mishra (2010). The educated person might have thought to have greater yield through use of fertilizers and minimizing yield losses using pesticides. Also, with the increase in their education status, they might be interested in service and following the traditional inorganic farming rather than innovative agricultural practices. However, the findings are in contrary with the findings of Adhikari et al (2018) who reported positively significant relationship between number of schooling years and adoption of agricultural technology. The positive significant effect of annual household income from agriculture on adoption of organic rice farming revealed from this study is synonymous with the findings of Subedi et al (2015); Gbetibouo (2009) and Deressa et al (2009). The increased agricultural income results to higher liquidity and greater ability for the farmers to bear risk as they will be in a better financial position to adopt new agricultural technology. Also, the study revealed positive and significant effect of membership of organization in adoption of organic rice farming. Similar findings have been reported in many studies (Timsina et al 2012, Subedi and Dhakal 2015, Adhikari et al 2018 and Subedi et al 2019a). Being the member of the organization, the farmers get opportunity to interact, hear, share and learn from each other regarding knowledge on improved agricultural technology. Also, the rapport between them works worth fully to make them convinced for adoption. The finding revealed- inverse relationship between size of land allocated for rice cultivation and adoption of organic rice farming is in line with the finding of Gairhe et al (2017) but is in contrary with Timsina et al (2012) regarding adoption of agricultural technology. The negative relation might be due to the reason that small scale farms would have done organic rice production by applying eco-friendly and sustainable farming practices aiming profit optimization without deterioration of resources; however, in larger farms the focus might be only on profit maximization. The mean land holding size of the farmers revealed from this study is 24 kattha $(0.8 \mathrm{ha})$ while mean size of rice cultivated land is 18.9 kattha $(0.63$ ha). Moreover, it has been reported that small landholders and marginal farmers predominate Nepalese agriculture with the average holding size of 0.8 ha (CBS 2011). So, it could be said that this finding would be more applicable to small scale and marginal farmers as compared to their counterparts.

Getting government subsidy in inputs (plastic drum to make botanical pesticides) other than seed and fertilizers, the probability of adoption of organic farming increases. This finding is supported by the studies (Mason and Smale 2013, Subedi et al 2019b) relating to adoption of improved agricultural technologies. Having information about climate change was found to have significant and positive effect on adoption of organic rice farming. The farmers who have heard about climate change might have incubated the issue for discussion in their agricultural group and the positive aspects of organic rice farming in relation to climate change mitigation might have been revealed over there, which encouraged the farmers for adoption of organic rice farming. This is in line with the findings of Singh (2015) and Ghimire (2016) regarding adoption of improved agricultural technology. 
Comparative financial analysis of organic versus inorganic rice production

The total variable cost of production per kattha in organic rice farming (N.Rs.3119) was found to be less than inorganic rice farming (NRs.3859) (Table 4). Research from numerous developing countries points to lower production costs in organic systems because fewer external inputs are used (Rosegrant and Ringler, 2005). Other studies have found that even without price premiums, farmers are adopting organic agriculture to save costs and achieve viable yields (Scialabba 2002). Moreover, the study revealed labor cost as the major cost item among the variable cost items which is synonymous to the findings of Adhikari (2011); also, the finding- lower labor cost and higher fertilizer cost in organic compared to inorganic production is in line of the findings of Adhikari (2009). The total returns from inorganic rice production (NRs. 7246) was found to be higher as compared to organic rice production (NRs. 7000) (Table 5). The higher return in inorganic rice production is due to its higher productivity $(171 \mathrm{~kg} / \mathrm{kattha})$ as compared to the productivity in organic rice production $(166 \mathrm{~kg} / \mathrm{kattha})$. The average productivity of rice in Chitwan district has been reported $3970 \mathrm{~kg}$ per hectare (MoALD, 2020). The findings of this study regarding total variable cost and total returns in organic and inorganic production is in line with the findings of Adhikari et al (2009) and Memon (2015). The gross margin in organic rice production (NRs. 3881/ kattha) was found to be higher than inorganic rice production (NRs. 3387/ kattha) which shows that organic rice production is financially sounder than inorganic rice production (Table 6). The higher gross margin in organic rice production despite lower total returns is due to the lower cost of production compared to inorganic rice production. Padel and Uli (1994) revealed that the organic farming under German conditions was highly profitable; lower yields for arable crops were compensated by reduced costs of inputs. Anderson (1994) also reported that the lower yields on organic farms contrasted with conventional inorganic farms were balanced by lower production costs. Also, the higher gross margin has been reported in organic carrot production than that of inorganic in the study conducted in Chitwan district of Nepal (Adhikari 2009).

The benefit cost ratio in both of the rice farming methods- organic as well as inorganic is greater than one indicating the financial viability; which means if one rupee money is invested in rice production, the return will be greater than one. In addition, the benefit cost ratio of organic rice production (2.2) was found to be higher as compared to inorganic rice production (1.9) which indicates the superiority of organic rice production to inorganic rice production in terms of financial viability (Table 6). The higher benefit-cost ratio in organic rice production compared to inorganic revealed from this study is supported by past researches (Adhikari et al 2009, Mehmood et al 2011a and Mehmood et al 2011b). The cost of production in organic rice farming is less than inorganic farming which had ultimately played a role for higher benefit cost ratio in organic rice production as compared to inorganic. Adhikari (2011) also conducted the study in organic rice farming in Chitwan and reported that the average benefit cost ratio was found to be 1.15. Also, Sapkota et al (2018) conducted a research on economics of rice production in Kathamandu district and has reported the BCR 1.89. Moreover, the BCR of rice in the central development region has been reported 2.83, which was highest among the five development region (Joshi, 2004).

Identification of major hindrances in adoption of organic rice farming

Lengthy certification process, lack of proper organic market, high cost of organic seed and fertilizer, lack of knowledge and trainings on organic farming and lack of government support such as grants and premium price were identified as the major hindrances in adoption of organic farming. Pokhrel and Pant (2009) also reported that the certification process is complicated and costly for smallholder Nepalese farmers, very hard to afford the costs. In addition, in line of the findings of this study, Pant (2006) reported that the plants nutrients supplied by organic manure is costly than from the chemical fertilizers. Moreover, he reported that there are limited interventions of government sectors in dissemination of knowledge and trainings related to organic farming. In addition, synonymous to the findings of this study, Parajuli (2020) also reported that lack of government support and premium price, lack of technical skills and proper markets allied with weak certification are the major problems for organic farming in Nepal. Moreover, it has been reported that lack of market information and infrastructures, issues of certification, lack of technical knowledge and skilled manpower are the major hindrances in adoption of organic farming in Nepal (Pokhrel 
and Pant 2009). Furthermore, Bhatt et al (2008) also reported that having no assurance for marketing of organic products and lacking the government support are the major bottlenecks in adoption of organic farming.

\section{CONCLUSION}

Organic rice farming has been explored as an economically viable and superior to inorganic farming. The benefit cost ratio and gross margin in organic rice production was found to be higher despite lower total returns, is due to the lower cost of production compared to inorganic rice production. The organic rice farming can be promoted by launching campaigns and awareness raising programs; also, the importance of organic rice farming can be made better understood to the farmers through informal education (trainings, seminars, and group discussions) rather than formal. Membership of agricultural organization and increment in agricultural income could encourage the farmers in adoption of organic rice farming. Moreover, to promote adoption, government should give subsidies on different inputs and should provide grants for organic rice farming, basically prioritizing the small-scale and marginal farmers. The lengthy certification process was identified as the first major hindrance in adoption of organic rice farming followed by lack of proper organic market, high cost organic seed and fertilizer, lack of knowledge and trainings on organic farming and lack of government support such as grants and premium price as the second, third, fourth and fifth hindrances respectively. Government should ensure the availability of subsidized inputs, promote group certification and establish proper marketing mechanism to enhance organic farming in Nepal. Also, there is a need of further research on organic certification, opportunities and challenges in marketing of organic products.

\section{ACKNOWLEDGEMENTS}

The authors would like to thank Agriculture and Forestry University for the technical support during the study period and the respondents of the study area for their warm response and cooperation during the field survey.

\section{REFERENCES}

Adhikari RK. 2009. Economics of organic versus inorganic carrot production in Nepal.The Journal of Agriculture and Environment.10: 27-33.

Adhikari RK. 2011. Economics of organic rice production. The Journal of Agriculture and Environment. 12:97-103.

Adhikari SP, KP Timsina and J Lamichhane. 2018. Adoption and impact of rainwater harvest technology on rural livelihoods: The case of Makwanpur district, Nepal. Rural Extension and Innovation systems Journal.14(1): 3440.

Anderson MD.1994. "Economics of organic farming in USA" in The economics of organic farming - An international perspective (ed.) by Lampkin N.H and Padel S., CAB International Publishers.

Bhatta GD, W Doppler and KB KC. 2008. Problems and Potentials of Organic Agriculture Development in Nepal. In: Paper presented in conference on International Research on Food Security, Natural Resource Management and Rural Development, 7-9 Oct 2008, University of Hohenheim, Stuttgart, Germany.

Bhatta GD, W Doppler and KB KC. 2009. Potential of Organic Agriculture in Nepal. The Journal of Agriculture and Environment.10:1-11.

CBS. 2012. National Population and Housing Census 2011. Central Bureau of Statistics, Government of Nepal, Kathmandu, Nepal.

Deressa TT, Hassan RM, C Ringler, T Alemu and M Yusuf. 2009. Determinants of farmer's choice of adaptation methods to climate change in the Nile Basin of Ethiopia. Global Environment Change. DOI: https://10.1016/j.gloenvcha.2009.01.002

DFID. 2004. Agricultural Sustainability. UK: Department for International Development.

Gairhe S, D Gauchan and KP Timsina. 2017. Adoption of improved potato varieties in Nepal. Journal of Nepal Agricultural Research Council.3:38-44.

Ghimire YN, KP Timsina, G Kandel, DB Thapamagar, S Gautam and B Sharma. 2016. Agricultural Insurance issues and factors affecting adoption: A case of banana growers in Nepal.Journal of Nepalese Horticulture.11: 74-82 
Gbetibouo GA. 2009. Understanding farmer's perceptions and adaptations to climate change and variability. The case of Limpopo Basin, South Africa.IFPRI Discussion Paper 00849.Environment and production Technology Division.International Food Policy Research Institute.Available at: www. ifpri. org/ pubs/ otherpubs.htm\#dp (Retrieved on 12th January 2013).

Hattam BC. 2006. Barriers to the adoption of organic agriculture: An investigation using the Theory of planned behaviour.

Inubushi K, H Sugii, S Nishino and E Nishino. 2001. Effect of aquatic weeds on methane emission from submerged paddy soil. American Journal of Botany.6(88): 975-979.

Joshi NP. 2004. Production and Marketing of Rice in different development regions of Nepal. Rampur, Chitwan, Nepal : Institute of Agriculture and Animal Science.

Kafle B. 2010. Determinants of Adoption of Improved Maize Varieties in Developing Countries: a Review. International Research Journal of Applied and Basic Sciences.1 (1):1-7.DOI:https://doi.org/10.1111/j.14779552.2004.tb00115.x.

Kassie M and P Zikhali. 2009. Sustainable land management and agricultural practices in Africa: Bridging the gap between research and farmers. Gothenburg, Sweden: University of Gothenburg.

Khaledi M, S Weseen, E Sawyer, S Ferguson and R Gray. 2011. Factors influencing partial and complete adoption of organic farming practices in Saskatchewan, Canada. Canadian Journal of Agricultural Economics.58 (1):37-56.

Khanal S and RR Kattel. 2015. Impact assessment of climate change on rice production and adaptation strategies of farmers in Kaski and Chitwan district, Nepal. Journal of Agriculture and Forestry University.2: 245-256.

Mason NM, and M Smale. 2013. Impacts of subsidized hybrid seed on indicators of economic wellbeing among smallholder maize growers in Zambia. Agricultural Economics.44(6):659-670.

Mehmood YB, M Anjum Sabir and M Arshad. 2011a. Benefit cost ratios of organic and inorganic wheat production; a case study of district Sheikhupura, World Applied Sciences Journal.13 (1): 175-180.

Mehmood Y, B Anjum and M Sabir. 2011b. Benefit cost ratio analysis of organic and inorganic rice crop production; evidence from district Sheikhupura in Punjab Pakistan, Pakistan Journal of Science.63: 174-177.

Memon IN, S Noonari, AS Ghouri, A Pathan, Z Memon, RH Jamali, SA Sial and M Pathan. 2015. Comparative economic analysis of organic and inorganic wheat production in District Matiari Sindh Pakistan, Journal of Natural Sciences Research.5:44-59.

MoALD. 2020. Statistical Information on Nepalese Agriculture 2018/2019. Agri Statistics Section, Monitoring, Evaluation and Statistics Division. Singha Durbar, Kathmandu, Nepal: Ministry of Agricultural Development.

Padel S and Uli Z. 1994. "Economics of organic farming in Germany" in The economics of organic farming - An international perspective (ed) by Lampkin N.H and Padel S., CAB International Publishers.

Pant KP. 2006. Organic Agriculture for Sustainable Development in Nepal.Paper presented in APO seminar on organic farming for sustainable development held in Colombo,11-15 Sept, 2006.

Parajuli, S, J Shrestha and S Ghimire. 2020. Organic farming in Nepal: A viable option for food security and agricultural sustainability. Archives of Agriculture and Environmental Science.5(2): 223-230, DOI: https ://dx.doi.org/10.26832/24566632.2020.0502021

Pokhrel DM and KP Pant. 2009. Perspective of Organic Agriculture and Policy Concerns in Nepal. The Journal of Agriculture and Environment.10: 89-99.

Rasul G and GB Thapa. 2004. Sustainability of ecological and conventional agricultural systems in Bangladesh: an assessment based on environmental, economic and social perspectives. Agricultural Systems 70: 327-351.

Rosegrant M and CA Ringler. 2005. Agriculture and achieving the Millennium Development Goals. Washington DC: Agriculture and Rural Development Department, World Bank.

Sapkota BK, JP Dutta,TR Chaulagain and S Subedi. 2018. Production and marketing of rice in Naghlebhare rice block, Kathamndu: an economic analysis, Nepalese Journal of Agricultural Sciences.16:145-155.

Scialabba NA. 2002. Organic Agriculture, Environment and Food Security. Rome: Food and Agriculture Organisation of the United Nations.

Singh M. 2015. Sustainability of organic farming compared to conventional farming in Chitwan district of Nepal. $\mathrm{Ph} . \mathrm{D}$ thesis dissertation. Graduate school for International Development and Cooperation, Hiroshima University, Japan.pp.59-62.

Subedi S and D Dhakal. 2015. Economics of poultry manure as an alternative to chemical fertilizer for agricultural production in Nepal. Journal of Institute of Agriculture and Animal Sciences.33-34: 259-268.

Subedi S, YN Ghimire and D Devkota. 2017. Socio-economic assessment on maize production and adoption of open pollinated improved varieties in Dang, Nepal. Journal of Maize Research and Development. 3(1):17-27.DOI: http://dx.doi.org/10.3126/jmrd.v3i1.18916 
Subedi S, YN Ghimire, SP Adhikari, D Devkota, HK Poudel and BK Sapkota. 2019a. Adoption of improved wheat varieties in eastern and western Terai, Nepal. Journal of Agriculture and Natural Resources.2(1):85-94. DOI: https://doi.org/10.3126/janr.v2i1.26047

Subedi S, YN Ghimire, SP Adhikari, D Devkota, J Shrestha, HK Poudel and BK Sapkota. 2019b. Adoption of certain improved varieties of wheat (Triticum aestivum L.) in seven different provinces of Nepal. Archives of Agriculture and Environmental Science.4(4): 404-409, DOI: https://dx.doi.org/10.26832/ 24566632.2019. 040406

Timsina, KP, KP Shrestha and S Pandey. 2012. Factors affecting adoption of new modern varieties of Rice in eastern Terai of Nepal. In the proceeding of 4th Society of Agricultural Scientist-Nepal (SAS-N) conference held at Lalitpur from 4-6 April, 2012. Nepal Agricultural Research Council (NARC) \& Society of Agricultural Scientists (SAS-N), Nepal. 48-54pp

$|1------||------| \mid$ 